\title{
The Use of an Idea Bank in Developing Business Operations
}

\author{
Pekka. Tervonen ${ }^{1}$, Harri. Haapasalo ${ }^{2}$ and Jukka Keinänen ${ }^{3}$ \\ ${ }^{1}$ Rautaruukki Plc, Raahe, Finland \\ ${ }^{2}$ Department of Industrial Engineering and Management, University of Oulu, Finland \\ ${ }^{3}$ Puulinnankatu, Oulu, Finland
}

\begin{abstract}
The objective of this study is to develop an operating model for the purpose of utilising an idea bank in the development of business operations. The study was carried out as a constructive interview survey. The study examines the development proposal activity in a company and the operating model which is created in this study includes a harmonised electronic recording system for development proposals. The study clarifies the existing models and procedures related to the employees' idea and suggestion schemes and continuous improvement. The idea bank model includes a description of the requirements set by development proposal activity to the model itself and the incorporated management system. The objectives of the idea bank model are to maintain the processes needed for the development proposal activity, and to be a tool towards harmonising and organising development proposal activities.
\end{abstract}

The idea bank model can be used to record different kinds of development proposals into a common operating model and system. The operating model consists of making a development proposal, handling and processing it, the implementation, reward, recording and retrieving of data related to the proposal and follow-up. The idea bank model may facilitate the employees' participation in development and innovation activities, as well as sharing knowledge and operating methods. The model allows development activities to be directed according to the company's needs, as well as the monitoring and analysis of operations. In addition, it enables the employees' know-how to be recorded in order to create a resource of data for the organisation.

Keywords: Continuous improvement, Idea bank, development proposal activities.

\section{Introduction}

In order to maintain competitiveness, companies must be able to change and innovate. According to Gopalakrishnan and Damanpour (1997), innovative companies are defined to be companies that succeed in creating innovations or be able to exploit them and adapt to changing circumstances, or both. According to Francis and Bessant (2005), a company's ability to innovate can be categorised into four areas: innovation in product improvement, process improvement, the positioning of the company or its products and innovation in the company's existing operating model. Sustainable competitiveness, however, depends on the company's ability to exploit and adapt to changes originating from innovations in processes and products. (Damanpour \& Gopalakrishnan, 2001).

Copyright (C) 2012 Pekka.Tervonen, Harri.Haapasalo and Jukka Keinänen. This is an open access article distributed under the Creative Commons Attribution License unported 3.0, which permits unrestricted use, distribution, and reproduction in any medium, provided that original work is properly cited. Contact author: Pekka.Tervonen E-mail: Pekka.Tervonen@ruukki.com 
Innovations open up new opportunities for the company. An innovation can be construed as an opportunity to develop the company's business. Ideas must be implemented and inventions commercialised and exploited in the company's products, production and administration alike. (Drejer, 2002.) According to Boeddrich (2004), the first step in the innovation process is to create a constant flow of ideas prior to establishing actual development projects. The company's efficiency, competitiveness and the ability to constantly create innovations depend, in addition to several other factors, on the participation of the company's employees (Tonnessen, 2005). According to Alves et al. (2007), innovative companies exploit various sources of ideas and encourage their employees to innovate, in order to obtain a constant flow of ideas.

Francis and Bessant (2005) show that there can be a number of approaches to examine the company's operations and various sources of improvement ideas. According to them, a decision to commence a change process can manifest itself in various ways. The company's employees are a source of potentially valuable innovations, and therefore, it is paramount that supervisors are able to collect and utilise the ideas expressed, their full potential and exploit the employees' ideas in problem solving (Fairbank \& Williams 2001). Employees may participate in innovation activities, directly or indirectly, at various levels, from making independent improvements to their own work station to extensive development proposals affecting the entire company (Tonnessen, 2005).

This study examines the models of continuous improvement and suggestion scheme, as well as the initial stages of an innovation process as parts of development and innovation activities. In addition, the study sheds light on how they act as a tool for business developments. The development proposal scheme in the target company consists of the improvement proposal activities, which, in turn, consist of continuous improvement activities and suggestion schemes, and ideas and inventions. The objective of this study is to create an operating model for an idea bank, which includes an electronic system that the company can use for its development proposal activities. The research is as follows:

\section{The target company does not have an operating model for taking advantage of an idea bank.}

The objective of this study is to create an operating model (Figure 1.), in which ideas, suggestion schemes and CI can be managed in one electronic system and which can be used to implement common operating models in the everyday operations of the target company.

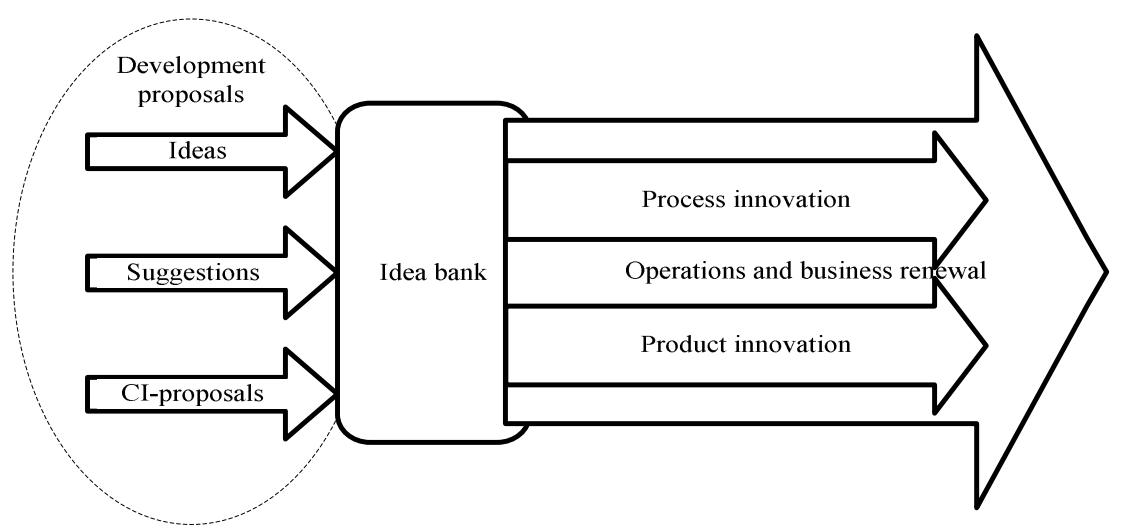

Figure 1. Using an Idea Bank in Developing Business Operations 
This study is constructive in nature, which, according to Järvinen and Järvinen (2000), can be characterised by its tendency to build new knowledge on the foundation of existing information. The constructive approach is a form of applied research, which aims to solve a problem and create new information on the subject (Kasanen et al. 1993). The study was carried out in compliance with the structure of a constructive study. According to Yin (2003), the objective of research methods is to present logical solutions. The quality of this study was assessed through its validity and reliability.

The first step was to carry out a preliminary survey, which took the form of a research plan. The requirements set for an idea bank operating model were examined on the basis of existing literature, and the current situation in the target organisation was mapped out. The interview questions were made on the basis of the literature, the idea and suggestion schemes of the target company, as well as its CI activities. The objective of the interview questions was to examine possible idea bank exploitation models in the target company in more detail and to collect data which was related to various idea bank operating models by means of interviews of a third-party interview. The data and alternatives collected during the interviews form the empirical part of this study.

A total of five subjects were interviewed. Three subjects were from the target company. The objective of the internal interviews was to describe the use of an idea bank in the target company and shed light on any existing systems. There were a total of two third-party interviewees. External interviews were used to gain information on operating models and systems that had common characteristics with the idea bank which was to be developed. The external interviews created a reference point for internal interviews and offered various alternative solutions for the building of an idea bank operating model.
The interview questions were sent to the subjects in advance, and they therefore had the opportunity to familiarise themselves with the questions prior to the interview. The interviews were recorded in order to ensure the reliability and correctness of the information. A preliminary summary was made of each interview. The summaries were given to the subjects so that they could verify the accuracy of the information given. An idea bank operating model was created for the target company on the basis of the literature and empirical research.

The implementation of the operating models and the suitability of the studied systems, to serve as a basis for an idea bank operating model, have also been assessed. The suitability of the systems was assessed by applying the Toddlergrade model developed for the target company. The Toddlergrade model is a maturity model developed for the company's ESSQ management. The model is applied from the PDCA cycle by William Deming. (Tervonen et al. 2009).

\section{Innovation Activity and Business Development}

An innovation activity should be seen as a large entity. In addition to new projects and processes, new technology may bring along new features and market opportunities. Business development must, therefore, be considered to be an important part of innovation activities (Drejer, 2002).

A business model must adapt to changes arising from innovations. The value of an innovation cannot be delivered or achieved without a business model (Teece, 2010). Technology generates less value, if a suitable business model cannot be found for it (Chesbrough, 2010). Technological innovations must often be launched on the markets and the new needs of customers must be met. As a consequence, a suitable business model is also required (Teece, 2010). 
The business operations of a company are often based on a business model, and every enterprise has its own model, be it visible or not (Chesborough, 2007). A business model does not, however, equal a strategy. A mere business model is not enough to succeed in fiercely competitive markets; a strategy states the areas, in which the company intends to exceed or differ from its competitors. (Magretta, 2002.) According to Osterwalder et al. (2005), a business model can describe business as a system, whereas a strategy describes the execution of a business plan or the company's actions.

A company's business model may present an outlook on how the company creates and produces value for its customers (Teece, 2010). Business models can also be used to identify the core parts of the company's business and their relations (Osterwalder et al., 2005). From the company's point of view, business models have two important functions: a creation of value and assuming value (Chesborough, 2007). According to Teece (2010), a business model describes the company's value creation system, how the company delivers value and benefits from it. This study examines the offering, value creation system and earnings logic of business models.

An offering refers to the end product of a value creation chain. Through its offering, a company can create value for its customers, for example, by the means of products, services, knowledge or a combination of these. (Kotler, 1997). The value creation system is based on a value chain. Porter (1985) uses the term 'value chain' to describe a system in which a company designs, manufactures, markets and delivers its products. Earnings logic describes where and how a company generates its profit (Rajala et al., 2001).

Creativity, ideas and innovations are concepts that are often used in the same context. According to Schilling (2008), an idea is a concept which has been imagined or outlined in one's own mind. According to
Damanpour et al., (2009) an idea can be attributed to new products, processes, markets or administrative structures. Fairbank et al, (2003) describes creativity as solving problems with new, practical solutions. Creativity can be defined as the generation of ideas and innovation can, then, be understood as the processing of these ideas (Alves et al., 2007). In business, creativity often refers to ideas that give rise to new product or process innovations (Gordon et al., 2008). Creativity is, therefore, strongly linked with innovation, also in the field of business.

There are a number of definitions for innovation. According to Gopalakrishnan and Damanpour (1997), innovation, at its simplest, means something new, whereas McAdam and McClelland (2002) consider innovation to be a gradual process stretching from the creation of an idea to its practical implementation. In their view, creativity is part of the idea creation process.

Innovation is also often connected with invention, which is often considered to be a short, once-off event. According to Garcia and Calantone (2002), in addition to a product development process, innovation can occur in processes that entail continuous improvements or modernisations.

In terms of business, innovation is often connected with commercial and technological aspects. Innovation requires the exploitation of ideas and the commercialisation of inventions (Drejer, 2002). It is often also described as a change, which a company can offer as an actual product or as a process innovation, which means the way a company produces the product it offers to its customers (Francis \& Bessant, 2005). According to Fairbank and Williams (2001), the impacts of innovations may cover everything from new products to minor improvement in processes.

There are several different definitions of innovation in the literature. One of the most commonly used ways is perhaps to consider innovations to be a part of process and 
product innovations, as was also stated by Francis \& Bessant (2005).

According to Gopalakrishnan et al. (1999), process and product innovations are related to know-how, which is a part of the systems, methods and individual employees of an organisation. The difference between process and product innovation is the target of the innovation (Gopalakrishnan \& Damanpour, 1997). According to Damanpour and Gopalakrishnan (2001), innovations which are related to products and technologies affect industries, whereas process innovations are primarily targeted at specific organisations. Garcia and Calantone (2002) state that the difference between process and product innovation is often difficult to define, because product innovations may have their origins in process innovations.

According to Garcia and Calantone (2002), innovativeness often refers to the novelty of an innovation, but one seldom pays attention to whose viewpoint the novelty is assessed. According to Drejer (2002), one possible way to assess the novelty of an innovation is to examine it from the viewpoint of the company and its field of industry. In addition, an innovation can be new to the individual, organisation or industry who are applying the said innovation (Damanpour et al., 2009). According to Carcia and Calantone (2002), innovativeness can be examined - regardless of one's viewpoint - as the degree of change in a technology or the markets.

Drejer (2002), however, describes innovation as a result of an innovation process. The entire innovation process must be in line with the company's strategy, in order for the company to guarantee a continuous flow of innovations (Koen et al., 2001). Koen et al. (2001) describes a three-stage innovation process that starts from the onset of the process, continues towards a systematic product or process development stages and terminates in a commercialisation.

An innovation process is described in various ways in the literature. For example, the innovation process described by Koen et al. (2001) divides the process into three subprocesses defined in the literature and it is, therefore, an illustrative example of the innovation process. Tidd et al. (2005) presents a general model of four common tasks in the innovation process of a company: 1) The company must observe its environment for innovation opportunities, 2) The company must choose the most lucrative opportunities to enhance its competitiveness, 3) The company must implement the chosen opportunities and develop them into products or processes and 4) The company must monitor the previous stages and collect and exploit information gathered from various stages in order to develop the process.

According to Khurana and Rosenthal (1998), the holistic innovation process management is based on creating connections between business, product strategy and decisionmaking during the early phases of an innovation process. Decision-making in the early phases of an innovation process should be based on the company's strategy (Khurana \& Rosenthal, 1998). According to Broeddrich (2004), innovations are considered to be successful in so far as they are linked to the company's strategy at an early stage and if the ideas which are suggested result in products that have clear advantages to competing products. Kim and Wilemon (2002a) also state that the early phases of an innovation process must be in accordance with the company's strategy and existing capabilities. A successful product development process can only be achieved if the early phases of the innovation process are based on the company's capabilities (Koen et al., 2001). Khurana and Rosenthal (1998) also underline the importance of integrating a business and product strategy on the early phases of an innovation process, for example, in creating product definitions. New products must be supported by development plans and testing and as possible new business (Khurana \& Rosenthal, 1998). 
According to Koen et al. (2001), the greatest improvement opportunities of an innovation process can be found during the early phases of the innovation process. According to Kim and Wilemon (2002b), the early phases of an innovation process consist of the recognition of an opportunity and the making of the decision to develop it further. According to Koen et al. (2001), however, the early phases of an innovation are actions which precede the formal project development of a product development process. The successful management of the early phases of an innovation process, therefore, includes an understanding of the form of the process and the consequences of actions taken within the process (Kim \& Wilemon, 2002b).

The importance of the early phases of an innovation process is highlighted since it precedes actual product or process development processes (Koen et al. 2001). The R\&D of the company benefits from a good organisation of the early phases of an innovation process, and its results affect any later stages of the process (Kim \& Wilemon, 2002a).

For Koen et al. (2001), the early phases of an innovation process are informal and unpredictable. The early phases of an innovation process could also be described as being creative actions or actions aimed at formulating an idea - through various stages - into a development proposal (Gordon et al., 2008). Boeddrich (2004) state that the early phases of an innovation process are considered to be informal and unpredictable, due to the impacts of creative elements on the innovation process. The early phases of an innovation process are challenging, as it is susceptible to great uncertainty and expectations, in addition to which, the skills and operating models of the various parts of an organisation merge during the early phases of the process (Khurana \& Rosenthal, 1998). Uncertainty is underlined in the cases of new products or changes in the markets, for example (Kim \& Wilemon, 2002a).
Also, Koen et al. (2001) say that the company's strategy, competition and the company's capabilities and technology affect the onset of an innovation process. According to Khurana and Roselthal (1998), if a company wishes to make the early phases of an innovation process more effective, the company must focus on the strategy, culture, processes and roles. The company must adapt its process to match the products, markets and its own organisation (Khurana \& Rosenthal, 1998).

According to Koen et al., (2001), the five elements of the early phases of an innovation process are: the identification of an opportunity, the analysis of the opportunity, the generation of an idea, selecting the idea to further development, and the development of a concept and technology. These five elements are included in a new concept development model by Koen et al. (2001). The underlying force, engine, of the model is support by the company management, whereas the outer circle consists of external factors that influence decision-making in other components. (Koen et al., 2001.)

Companies often identify opportunities that they want to exploit in line with their business goals. The opportunities may vary from minor improvements to major overhauls (Koen et al., 2001). During an innovation process, companies must observe their environment, in order to identify threats and opportunities (Tidd et al., 2005).

A company then examines an opportunity that it has identified, obtains further information and, if required, invests additional resources in its analysis, in order to better assess the impacts of the opportunities which have been identified for, among others, its business (Koen et al., 2001).

An opportunity is developed into an idea and during the idea generation phase described by Koen et al. (2001), an opportunity evolves 
into a concrete idea. The process may be repeated several times and ideas are used to generate, analyse, combine, process and update other ideas. This phase may include idea banks and brainstorming operations, which are used to develop and collect new ideas or further develop existing ones. (Koen et al., 2001.)

Due to the large number of ideas generated, selecting the right one is often challenging for the company. In order to identify viable ideas that are useful to the company's business, they must be examined from the viewpoints of the company's capabilities, competition, available technology and markets, for example. (Koen et al., 2001.) As an idea becomes better defined and less unclear, it usually moves onto the development stage (Kim \& Wilemon, 2002b).

The concept is further developed and its business opportunities and risks are assessed. The development of the concept can be organised in various ways, depending on how much resources it requires and what kind of a company is exploiting the concept. (Koen et al., 2001.)

\section{An Operating Model for an Idea Bank}

An operating model of an idea bank of the case company was developed as a result of this study. The operating model combines idea and suggestion schemes and CI activities with the idea bank system. The idea bank operating model which was developed refers to factors of a development proposal activity found from the literature and empirical research, as well as characteristics of systems related to operations. The objective of the idea bank system is to, both maintain development proposal processes and to work as a tool in harmonising and organising development proposal activities. The operating model which was developed for the idea bank is illustrated in the flow chart in Figure 2.

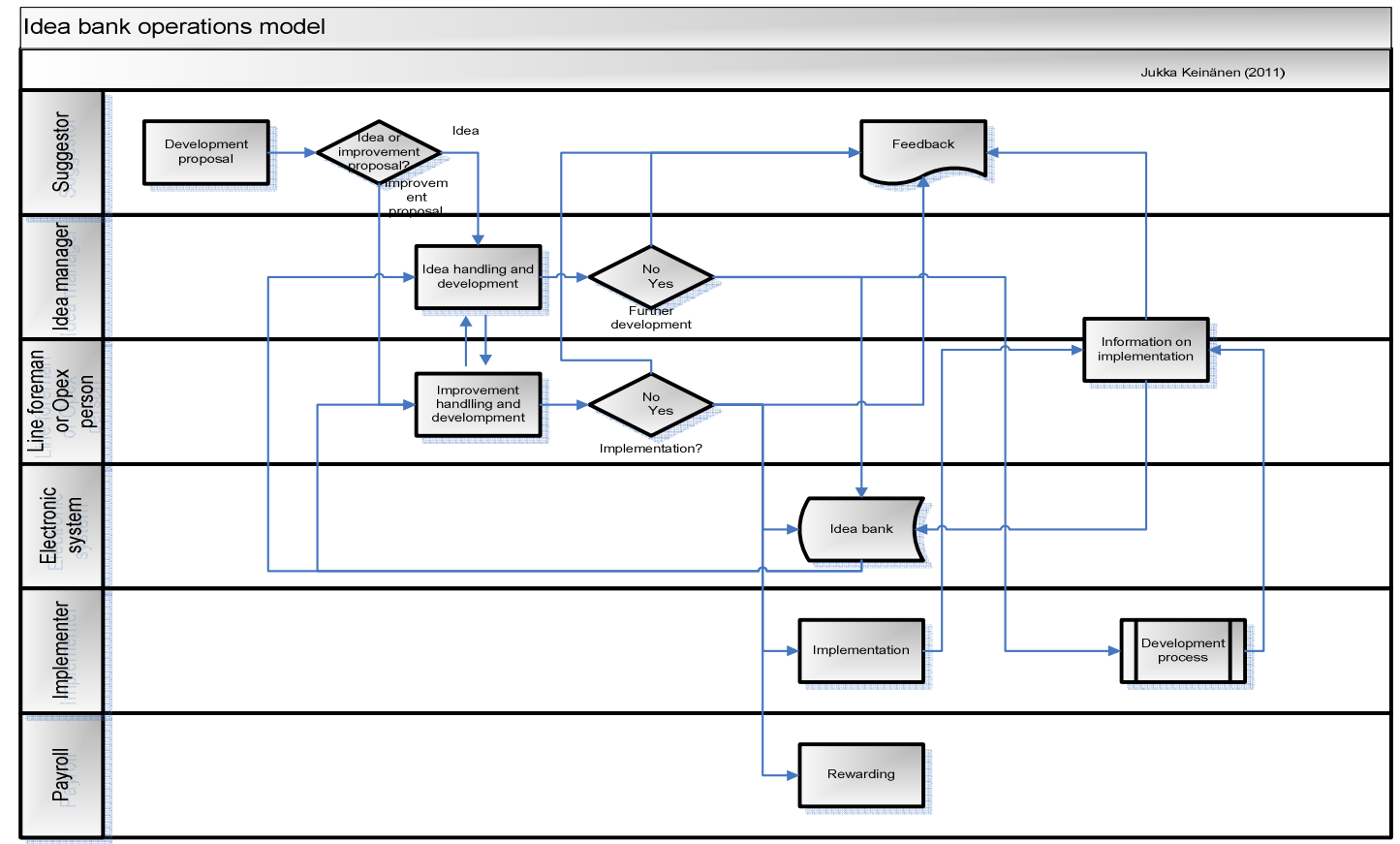

Figure 2. An Operating Model for the Idea Bank. 
The idea bank system must have the functionalities to make, receive and process development proposals, as well as for the organising of the implementation of an idea (Boeddrich, 2004; Bessant \& Francis 1999). The objective of the idea bank system is that suggestors can make their development proposals in one system, regardless of the type of their proposal or their location within the company. The development proposals are processed and further developed through the system, which is also used for steering and monitoring the implementation of proposals. The system functions as a databank that can be used to steer and maintain operations. Furthermore, it can be used to direct and follow up development proposal activities.
The idea bank system consists of the following components: making, handling and further developing a proposal, the implementation of development proposals and rewarding the suggestor. In addition, the system has components for recording and retrieving data, as well as monitoring operations. Table 1 summarises the main functionalities of the idea bank operating model. Some clarifications are given for development proposal processes, in order to make them mutually compatible and functional in a single electronic system. The solutions for implementing operating models for development proposal activity are based on the literature and empirical research.

Table 1. Components of the Operating Model of the Idea Bank

\begin{tabular}{|l|l|}
\hline $\begin{array}{l}\text { System } \\
\text { Functions }\end{array}$ & \multicolumn{1}{|c|}{ Description } \\
\hline $\begin{array}{l}\text { Making a development } \\
\text { Proposal }\end{array}$ & $\begin{array}{l}\text { Development proposals can also be made by a group or anonymously. } \\
\text { Development and recording, prior to directing the proposals for handling. A } \\
\text { description includes the proposal type, object, title, text field and attachments. A } \\
\text { possibility to link up with another proposal. }\end{array}$ \\
\hline $\begin{array}{l}\text { Handling and } \\
\text { developing a } \\
\text { development proposal }\end{array}$ & $\begin{array}{l}\text { Each proposal type is handled in an appropriate process. Proposals can be } \\
\text { transferred between processes or units. Statement requests and free feedback. } \\
\text { The individuals who are to be informed of the proposal are identified. }\end{array}$ \\
\hline $\begin{array}{l}\text { Recording and } \\
\text { retrieving data }\end{array}$ & $\begin{array}{l}\text { The data which is recorded during the process is saved, in addition to metadata } \\
\text { on the stages of the handling process. Data is retrieved using both metadata and } \\
\text { word search. A user-specific view on one's own development proposals. Mark } \\
\text { and reminder of reconsideration. Monitoring the subjects of the proposals. }\end{array}$ \\
\hline $\begin{array}{l}\text { Implementation and } \\
\text { rewarding }\end{array}$ & $\begin{array}{l}\text { Tasks related to the implementation and the monitoring of the implementation. } \\
\text { Rewarding practices in compliance with improvement proposal activities. The } \\
\text { rewarded development proposal is followed up in the system until its } \\
\text { implementation has been carried out. }\end{array}$ \\
\hline Follow-up & $\begin{array}{l}\text { Periodic statistics from different organisational levels on the participation rate, } \\
\text { handling throughput times and acceptance percentages. Real time information } \\
\text { on the participation rate. Activities are directed by means of campaigns. } \\
\text { Recording information in the company's intranet. Creation of e-mailing groups. }\end{array}$ \\
\hline General properties & $\begin{array}{l}\text { One system, regardless of the location and the type of the development } \\
\text { proposal. The system functions as a data bank, as a tool for steering } \\
\text { development proposal activities and as a communication forum. }\end{array}$ \\
\hline
\end{tabular}

In order to ensure the active participation of employees in the company's development activities and to maintain a constant flow of ideas, the company should create an easily accessible forum for the making and collecting of proposals (Boeddrich, 2004).
The generation of ideas and creative activity are only possible if there is interaction and a sharing of ideas. (Gordon et al., 2008). It should also be possible for the suggestor to communicate his or her idea to other users of the system (Boeddrich, 2004). The literature 
suggests that in order to ensure proper functioning of the innovation process and the system, it is essential to direct the suggestion scheme in such a way that proposals can be handled in an efficient way in the system (Boeddrich, 2004; Gorski \& Heinekamp, 2002).

The literature shows that those processing development proposals must be able to link proposals to the right problems and themes (Boeddrich, 2004). Furthermore, their assessment must be based on the capabilities and goals of the company (Kim \& Wilemon, 2002a; Koen et al., 2001). The literature suggests that the further development of development proposals requires interaction, and, therefore, the process is often carried out in an informal way (Boeddrich, 2004). There may also be several stages in the further development process (Gordon et al. 2008; Koen et al., 2001). The opportunity to co-operate supports the creation of development proposals and development, as well as the implementation of proposals (Tarafdar \& Gordon, 2007). The literature emphasises openness as an important factor. For example, Fairbank \& Williams (2001) state that the system should allow the monitoring of the handling process, as well as communication between the suggestor and those handling the proposal.

There are repeating stages in the further processing of an idea, which take place during the early stages of an innovation process (Koen et al., 2001), and, therefore, data which is related to the idea and any changes in the data must be recorded and be made accessible to all of the participants of the development work. Ideas which are recorded in the idea bank may encourage other users to develop new ideas or further develop existing ideas (Koen et al., 2001). The research of Gopalakrishnan et al. (1999) indicates that the data which is included in an innovation may affect its preconditions of success.

According to the literature, the assessment of propositions significantly affects the efficiency of the system (Gorski \& Heinekamp, 2002). The system helps to understand the importance of suggestions and innovations, to steer activities in the long term and to set suitable criteria for development proposals (Tarafdar \& Gordon, 2007). Goals must be set for activities and cooperation must be encouraged (Gorski \& Heinekamp, 2002). In addition, operations must be monitored in order to be able to develop them (Boeddrich, 2004). When examining an innovation process, it is important to understand the consequences of the results and the efficiency of the process (Kim \& Wilemon, 2002a), which is also supported by various statistics on the participation rate generated in the empirical research.

According to the literature, the implementation of development proposals is also a factor that maintains suggestion scheme activities (Rapp \& Eklund, 2002). Participation in the implementation of an idea or following up the implementation process is also considered to be encouraging factors (Gorski \& Heinekamp, 2002). Thanks to the system, sufficient resources can be allocated towards the implementation. Rewarding is often highlighted as an important motivational factor in literature. In addition to rewards, the providing of positive feedback on participation also encourages employees to share their ideas (Fairbank \& Williams, 2001). The literature also indicates that quick and sufficient feedback encourages and motivates employees to maintain development proposal activities (Rapp \& Eklund, 2002). A transparent handling process ensures employees that the process works well and that their suggestions are considered fairly (Fairbank \& Williams, 2001). Rewarding, which is a part of the idea bank system, increases transparency and thus indicates that the rewarding is both accurate and fair.

The implementation of the suggested operating model requires that the electronic system is harmonised to match the development proposal process. Operating 
models which are made for development proposal activities and harmonising practices that are already used in different units of the Group, also set certain requirements for a Group-wide system. Therefore, the implementation of the system requires that the operating models of a development proposal activity become established in different units. Table 2 assesses four systems which were examined in interviews and their suitability to serve as a basis for the operating model of an idea bank. The evaluation model is in line with the maturity model developed for the improvement of
ESSQ management in the company. (Tervonen et al. 2009.) At the roll-over level, the system does not have the function required for an idea bank. At the crawl level, the function partly exists, but needs to be altered and/or their properties must be expanded. At the walk level, the function must be better defined and harmonised within the idea bank operating model, whereas in the run level, the said function is ready to be implemented in the suggested operating model. The level of preparedness of the systems is illustrated in Table 2 .

Table 2. The Level of Preparedness of the Systems.

\begin{tabular}{|c|c|c|c|c|c|}
\hline Functionality & Orchidea & $\begin{array}{c}\text { Notes } \\
\text { suggestion }\end{array}$ & Safety tool & $\begin{array}{l}\text { Hr Router } \\
\text { (external) } \\
\end{array}$ & Scale \\
\hline General features & Walk & Roll-over & Walk & Walk & Run \\
\hline Making proposals & Walk & Crawl & Crawl & Walk & Walk \\
\hline $\begin{array}{c}\text { Processing and } \\
\text { development }\end{array}$ & Walk & Crawl & Crawl & Walk & Crawl \\
\hline Data storing and access & Walk & Crawl & Walk & Walk & Roll-ove \\
\hline $\begin{array}{c}\text { Implementation and } \\
\text { rewarding }\end{array}$ & Roll-over & Walk & Crawl & Walk & \\
\hline Monit oring & Crawl & Crawl & Crawl & Walk & \\
\hline
\end{tabular}

\section{Conclusion}

Development and innovation activities allow organisations to strive for improvements at different levels, from small-scale improvements to revolutionary innovations incubated from an idea through a development process. Development and innovation activities range from the development of products and processes to the development of operations and business. The company's employees are an important source of business developments and new ideas. The important organisational development and innovation activity models include continuous improvements, suggestion schemes and the early stages of an innovation process. The operating model and system of an idea bank must be constructed to meet the needs of the company. The operating model allows all employees to participate and offers a common, easy-to-use channel for participation.

In this study, the idea and suggestion schemes, as well as CI operating models, were combined to create a model for an idea bank. The model highlights the importance of combining all development proposal types into one operating model and system covering the entire target company. The most important characteristics of the operating model are an easy participation in all of the tasks, the sharing of information and communication, transparent activities, as well as an efficient implementation and follow-up of development proposals. The idea bank operating model consists of the making of a development proposal, its 
handling and further development, implementation and rewarding. The important functions of the operating model are efficient data processing and follow-up, allowed by an electronic system. Further research is, however, still required in a more detailed definition of the functionalities of the electronic system and the testing of the properties with a pilot project.

The essential characteristics of the idea bank operating model include an openness and ease of use. The operating model allows efficient communication, the sharing of ideas and the making of development proposals, in such a way that they can be further developed and exploited. The directing of development proposals towards the right people for assessment and development is essential for the further processing and exploitation proposals, in addition to which the handling and further development process must be open to all. A company can use the idea bank operating model to collect, exploit and share information related to development and innovation activities. In addition to collecting the information, the company analyses the data and exploits it in innovations, as well as in the development and directing of the operating model itself. At the practical level, the successful idea bank operating model for development and innovation is based on a company-wide easyto-use electronic system.

\section{References}

Alves, J., Marques, M. J., Saur, I. \& Marques, P. (2007). "Creativity and Innovation through Multidisciplinary and Multisectoral Cooperation," Creativity and Innovation Management 16(1):27-34.

Boeddrich, H.- J. (2004). "Ideas in the Workplace: A New Approach towards Organizing the Fuzzy Front End of the Innovation Process," Creativity and Innovation Management 13(4): 274-285.

Chesbrough, H. (2007). "Business Model Innovation it's not Just about Technology
Anymore," Strategy \& Leadership 35(6):1217.

Chesbrough, H. (2010). "Business Model Innovation, Opportunities and Barriers," Long Range Planning 43(2-3):354.

Damanpour, F. \& Gopalakrishnan, S. (2001). "The Dynamics of the Adoption of Product and Process Innovations in Organizations," Journal of Management Studies, 38(1): 45-65.

Damanpour, F., Walker, R. M. \& Avellaneda, C. N. (2009). "Combinative Effects of Innovation Types and Organizational Performance a Longitudinal Study of Service Organizations," Journal of Management Studies 46(4): 650675.

Drejer, A. (2002). "Situations for Innovation Management: Towards a Contingency Model," European Journal of Innovation Management. 5(1): 4-17.

Fairbank, J. F., Spangler, W. E. \& Williams, S. D. (2003). "Motivating Creativity through a Computer-Mediated Employee Suggestion Management System," Behaviour \& Information Technology 22(5):305-14.

Fairbank, J. F. \& Williams, S. D. (2001). "Motivating Creativity and Enhancing Innovation through Employee Suggestion System Technology," Creativity and Innovation Management 10(2): 68-74.

Francis, D. \& Bessant, J. (2005). "Targeting Innovation and Implications for Capability Development," Technovation 25(19): 171183.

Garcia, R. \& Calantone, R. (2002). "A Critical Look at Technological Innovation Topology and Innovativeness: A Literature Review," The Journal of Product Innovation Management 19(2): 110-132.

Gopalakrishnan, S. Bierly, P. \& Kessler, E. H. (1999). "A Re-Examination of Product and Process Innovations Using a Knowledge- 
Based View," The Journal of High technology management research 10(1):147-166.

Gopalakrishnan, S. \& Damanpour, F. (1997). "A Review of Innovation Research in Economics, Sociology and Technology Management," Omega 25(1): 15-28.

Gordon, S., Tarafdar, M., Cook, R., Maksimoski, R. \& Rogowitz, B. (2008). "Improving The Front End of Innovation With Information Technology," Research Technology Management 51(3):50-58.

Gorski, C. \& Heinekamp, E. J. (2002). 'Capturin Employee Ideas for New Products,' In: Belliveau, P., Griffin, A. \& Somermeyer, S. (2002). The PDMAToolbook for New Product Development. Wiley \& Sons, New York.

Järvinen, P. \& Järvinen, A. (2000). 'Tutkimustyön Metodeista,' Tampere: Opinpaja Oy 211 s.

Kaplan, R. S. \& Norton, D. P. (2004). 'Strategy Maps: Converting Intangible Assets into Outcomes,' Harvard Business School.

Kasanen, E., Lukka, K. \& Siitonen, A. (1993). "The Constructive Approach in Management Accounting Research," Journal of Management Accounting Research 5: 243264.

Khurana, A. \& Rosenthal, S. R. (1998). "Towards Holistic "Front Ends" in New Product Development," Journal of Product Innovation Management 15(1): 57-74.

Kim, J. \& Wilemon, D. (2002a). "Strategic Issues in Managing Innovation's Fuzzy FrontEnd," European Journal of Innovation Management 5(1):27-39.

Kim, J. \& Wilemon, D. (2002b). "Focusing the Fuzzy Front-End in New Product Development," R\&D Management, 32(4): 269-279.

Koen, P., Ajamian, G., Burkart, R., Clamen, A., Davidson, J., D’Amore, R., Elkins, C., Herald, K.,
Incorvia, M., Johnson, A., Karol, R., Seibert, R., Slavejkov, A. \& Wagner, K. (2001). "Providing Clarity and a Common Language to the "Fuzzy Front End"," Research Technology Management. 44(2): 46-55.

Kotler, P. (1997). 'Marketing Management: Analysis, Planning, Implementation, and Control,' 11th ed. Upper Saddle River: Prentice-Hall International, Inc.

Magretta, J. (2002). "Why Business Models Matter," Harvard Business Review 80(5):8692.

McAdam, R. \& McClelland, J. (2002). "Individual and Team-Based Idea Generation within Innovation Management: Organisational and Research Agendas," European Journal of Innovation Management 5(2): 8697.

Osterwalder, A., Pigneur, Y. \& Tucci, C. L. (2005). "Clarifying Business Models Origins, Present, and Future of the Concept," Communications of the Association for Information Systems 16(1):1-25.

Porter, M. E. (1985). "Competitive Advantage: Creating and Sustaining Superior Performance," New York: The Free Press.

Rajala, R., Rossi, M., Tuunainen, V. K., Rautiainen, K. \& Korri, S. (2001). 'Software Business Models: A Framework for Analyzing Software Industry,' Technology Review, Helsinki: TEKES.

Rapp, C. \& Eklund, J. (2002). "Sustainable Development of Improvement," Total Quality Management 13(7): 945- 969.

Schilling, M. A. (2008). Strategic Management of Technological Innovation, 2nd edition. McGrawHill.

Tarafdar, M. \& Gordon, S. R. (2007). "Understanding the Influence of Information Systems Competencies on Process Innovation: A Resource-Based View," Journal 
of Strategic Information Systems 16(4):353392.

Teece, D. J. (2010). "Business Models, Business Strategy and Innovation," Long Range Planning 43: 172-194.

Tervonen, P., Alapiha, J. \& Haapasalo, H. (2009). "Benchmarking ESSQ Management System through Tailored Maturity Model," International Journal of Management \& Enterprise Development 7(3): 262-280.

Tidd, J., Bessant, J. \& Pavitt, K. (2005). Managing Innovation. Integrating Technological, Market and Organizational Change, 3rd edition, Wiley, 2005.

Tonnesen, T. (2005). "Continuous Innovation through Company Wide Employee Participation," The TQM Magazine 17(2): 195-207.

Yin, R. K. (2003). 'Case Study Research: Design and Methods,' 3rd ed. Thousand Oak, California: Sage Publications. 